NOTICE: this is the author's version of a work that was accepted for publication in China Economic Review. Changes resulting from the publishing process, such as peer review, editing, corrections, structural formatting, and other quality control mechanisms may not be reflected in this document. Changes may have been made to this work since it was submitted for publication. A definitive version was subsequently published in China Economic Review, Vol. 23, No. 1 (2012). DOI: 10.1016/j.chieco.2011.08.008 


\title{
CHANGES OVER TIME IN THE RETURN TO EDUCATION IN URBAN CHINA: CONVENTIONAL AND ORU ESTIMATES
}

\author{
Weiwei Ren \\ Business School \\ University of Western Australia \\ \& \\ Mathematics School \\ Yunnan Normal University \\ and \\ Paul W. Miller \\ School of Economics and Finance \\ Curtin University
}

\begin{abstract}
Studies of the return to education in urban China have reported that this has increased over time, and that females typically have a higher return than males. In this paper we adopt a framework provided by the over education/required education/under education literature, and the decomposition developed by Chiswick and Miller (2008), to investigate the reasons for these findings. The finding by Chen and Hamori (2009), from analysis of data for 2004 and 2006, of the return to schooling for males exceeding that for females, is also examined using this decomposition.
\end{abstract}

Keywords: China, Schooling, Earnings, Rates of Return, Urban Areas

JEL Codes: J31, J62, J70

* Ren acknowledges financial support from the University of Western Australia via a University Postgraduate Award and from the Australian Research Council via a Postgraduate Scholarship. Miller acknowledges financial assistance from the Australian Research Council. We wish to thank Corinne Hooi for research assistance, and Meng Xin and an anonymous referee for helpful comments.

Address for correspondence: Paul W. Miller, School of Economics and Finance, Curtin University, GPO Box U1987, Perth, WA 6845, Australia, Email: Paul.Miller@curtin.edu.au, Telephone: +61 89266 7758, Fax: +61 892663026 


\section{CHANGES OVER TIME IN THE RETURN TO EDUCATION IN URBAN CHINA: CONVENTIONAL AND ORU ESTIMATES}

\section{INTRODUCTION}

Research into the return to education in urban China has documented three main findings. First, the return to education has increased over time. For example, Zhang et al. (2005) report that the return to education was around 4 percent in 1988, and around 10 percent in 2001. This increase has been largely attributed to the country's economic transformation. Second, the payoff to education for females exceeds that for males. Thus, Zhang et al. (2005) report that in 1988 the return to education for females, at 5.2 percent, was 2.3 percentage points greater than that for males (2.9 percent). This situation is similar to that in many Western countries (see, for example, Chiswick and Miller's (2010a) analyses for Canada). Third, the gender differential in the return to education appears to have widened over time. Zhang et al. (2005), for example, reported that their analyses for the period 1988-2001 show that the gender gap in the returns to education was at its lowest in 1993 (1.9 percentage points) and at its greatest in 2001 (4.8 percentage points).

Economic research of this type into the return to education has been argued to be important because of the insights that it can offer into the structure and operation of the labor market (see Chen and Hamori, 2009). One of the ways it can do this is by informing on allocative efficiency. From this perspective, the standard analysis, based on a human capital earnings function, can provide information on the profitability of investment in education, and variations in this across regions and time, though it does this largely from a labor supply perspective. In contrast, the over education/required education/under education literature (Hartog, 2000) gives explicit recognition to the demand side of the labor market. It does this by distinguishing between years of education that are standard for the occupations in which the workers are employed, 
years of education that are surplus to the usual levels of education in the workers' occupations, and shortfalls in the education levels of workers compared to the standards for the occupations in which they are employed. Through estimating earnings equations that include variables for each of these potential components of a worker's formal education, insights can be gained into the allocative function of labor markets (see Chiswick and Miller, 2008). As Hartog (2000, p.131) notes with respect to this variant of the earnings equation "...the specification establishes a link with the demand side of the labour market...with allocation processes and with immediately visible variations in rewards for individuals with identical schooling operating in different positions".

In this paper we use an over education/required education/under education (ORU) specification of the earnings equation (see Hartog, 2000), together with a related decomposition of the return to education in the conventional (or Mincer) human capital earnings equation developed by Chiswick and Miller (2008), to offer new insights into the changes over time in the return to education in urban China. The use of the decomposition of Chiswick and Miller (2008) allows weights to be attributed to the contributions that correctly matched education, years of education that are surplus to the usual standard of the worker's occupation, and shortfalls in education compared with the usual standards in the occupation of employment, make to the quite spectacular increase in the profitability of investment in education in urban China in recent years, as well as to the gender differences in the return to education.

The structure of this paper is as follows. Section II provides a brief overview of recent studies of the determinants of earnings in urban China. Section III outlines the methodological framework from Chiswick and Miller (2008). Section IV 
introduces the data set of the China Health and Nutrition Survey (CHNS), which is used in the empirical section. Section V presents the regression results (from both conventional earnings equations and an Over education/Required education/Under education, or ORU, earnings function) and the findings from application of the decomposition of Chiswick and Miller (2008). This section also offers comparisons with rural areas. Section VI draws conclusions on empirical regularities and irregularities.

\section{LITERATURE REVIEW}

There is now a substantial literature covering the return to education in urban China. The most widely-used data for this type of study in urban areas are the first two waves of the Chinese Household Income Project (CHIP), conducted in 1988 and 1995. ${ }^{1} \mathrm{Li}$ and $\mathrm{Li}$ (1994) used the first of these waves. Based on a simple specification of the earnings equation that contained only variables for years of education, experience and experience squared, they reported that the return to education in urban areas was 2.5 percent for males and 3.7 percent for females. Similar returns to education, for both males and females, were reported by Liu (1998), from analysis of the same data set, though using a much more extensive specification of the earnings equation that also contained variables for occupation and industry of employment, region of residence, and ownership type.

Lai (1998) extended this research by utilising the 1995 wave of CHIP. Using the same model as $\mathrm{Li}$ and $\mathrm{Li}$ (1994), Lai (1998) reported that the return to education

\footnotetext{
${ }^{1}$ CHIP was a joint research project between the Institute of Economics, Chinese Academy of Social Sciences and the Ford Foundation. Support was also provided by the Columbia East Asian Institute and the City University of New York. The sample's urban observations were obtained from Liaoning, Shanxi, Jiangsu, Guangdong, Anhui, Hunan, Hebei, Gansu and Yunnan provinces as well as from Beijing. Three surveys of this project were conducted in 1988, 1995 and 2001.
} 
for males had increased to 5.14 percent by 1995 and the return to education for females had increased to 5.99 percent. A similar pattern emerges from Li's (2003) study of these data using an earnings function that also included dummy variables for ownership type, industry, province, Party membership, ethnic minority and for youth "re-education". Thus the return to education was reported in this study to be 6.9 percent for females and 4.3 percent for males. ${ }^{2}$

Gustafsson and Li (2000) examine both the 1988 and 1995 waves of CHIP, using a common specification of the earnings equation. This was based on six dummy variables for level of education, and included controls for age, minority status, party membership, sector, occupation, ownership type, industry, region of residence and permanent/temporary status of the job. They reported that the effects of education increased dramatically over time, and that the "Effects of education are somewhat larger for female workers than for male workers" (p.319).

A higher return to education for females than for males in urban areas has also been reported in analyses of other data sets. Using the China Urban Households Survey (CUHS) conducted by China's National Bureau of Statistics from 1988 through $2001,{ }^{3}$ Zhang et al. (2005) reported that the return to education for females exceeded that for males by an average of about 60 percent over this thirteen-year period, and the gender differential in returns has tended to widen over time. Thus, while the return to education for females increased from 5.2 percent in 1988 to 13.2

\footnotetext{
${ }^{2}$ Other studies of the 1988 and 1995 waves of CHIP, which do not distinguish between males and females, also report rapid growth in the return to education, whether assessed using a continuous years of education variable or dummy variables for level of education. See, for example, Knight and Song (2003) and Yang (2005). Fleisher and Wang (2005) similarly report growth in the return to education between 1975 and 1990, based on retrospective information on income collected in 1994. Meng and Kidd (1997), who study change over the earlier period of 1981 to 1987, however, reported only a modest change to the return to education.

${ }^{3}$ The CUHS is conducted by the Urban Socio-Economics Survey Organization of the State Statistical Bureau. It covers 103 cities and 80 counties in two municipalities (Beijing and Chongqing) and 8 provinces (Shaanxi, Liaoning, Jiangsu, Anhui, Hubei, Guangdong, Sichuan and Gansu).
} 
percent in 2001, that for males only increased from 2.9 percent in 1988 to 8.4 percent in 2001. Similar changes over time are presented in Chen and Ju's (2004) analysis of these data for the period 1996-2000, and in Li and Ding's (2003) analysis of the 1995 and 1999 surveys conducted by the Income Distribution Group and Urban Poverty Group of the Institute of Economic Studies at the Chinese Academy of Social Sciences. $^{4}$

Maurer-Fazio (1999) combined analyses of the 1988 CHIP and data for 1992 from the Chinese Labour Market Research Project (CLMRP). ${ }^{5}$ In this analysis the return to education from the 1988 CHIP was reported as 2.9 percent for males and 4.5 percent for females. For 1992 the respective returns were 3.74 percent and 4.94 percent. Females had a higher return than males in each of the ownership types (State, Collective, Joint Venture) examined for 1992, and in each ownership type other than the very small number of private firms in the 1988 CHIP.

In contrast to these studies, Chen and Hamori (2009) reported that, in analyses of more recent data, the return to education for males exceeds that for females. Their study was based on data from the Chinese Health and Nutrition Survey (CHNS) for 2004 and 2006. Their OLS estimates of the return to education, which offer the best basis for comparison with the extant literature, were 8.06 percent for males and 7.67 percent for females. ${ }^{6}$ The reasons for the similarity of the return to education for

\footnotetext{
${ }^{4}$ The first sample survey covers the municipality of Beijing and ten provinces, namely Shanxi and Gansu in Western areas, Liaoning in Northwest areas, Jiangsu and Guangdong in coastal areas, Anhui, Hubei and Henan in Mid areas and Sichuan and Yunnan in Southwest areas. It surveys the households from 1990-1995. The second sample is drawn from the first one and covers Beijing and five provinces, which are Gansu in the West, Liaoning in the Northeast, Jiangsu in the coastal regions, Henan in the Central areas and Sichuan in the Southwest. The second survey covers 1996-1999.

${ }^{5}$ The CLMRP was conducted by the Economics Institute of the Chinese Academy of Social Sciences and the Labor Science Research Institute of the Ministry of Labor. It covered 12 provinces.

${ }^{6}$ The data set they used is the same as the data set used in the current paper. Further details can be found in Section IV.
} 
males and females in their study are examined below using the approach of Chiswick and Miller (2008).

\section{METHODOLOGY}

The approach used in this study is based on Chiswick and Miller's (2008) analysis of the smaller return to education for immigrants than for the native born in the US. It has been applied in analyses of the gender differential in the return to education in rural China in Miller and Ren (2011), and so only a brief exposition is offered here.

The starting point for the Chiswick and Miller (2008) approach is the ORU model of earnings determination. In this model the natural logarithm of earnings (ln y) is related to the years of required education in the worker's occupation (REQ), any years of over education (OVER) or under education (UNDER) for the worker, labor market experience (EXP) and its square, and other variables, such as location and marital status, that are usually held to affect earnings. That is:

$$
\ln y_{i}=\alpha_{0}+\alpha_{1} \mathrm{OVER}_{i}+\alpha_{2} \mathrm{REQ}_{i}+\alpha_{3} \mathrm{UNDER}_{i}+\alpha_{4} \mathrm{EXP}_{i}+\alpha_{5} \mathrm{EXP}_{i}^{2}+\ldots \ldots
$$

The first step in the Chiswick and Miller (2008) decomposition involves using estimates of equation (1) for females to predict earnings for each female at a particular level of education. ${ }^{7}$ Hence:

$$
\begin{aligned}
\ln \mathrm{y}=\alpha_{0}+\alpha_{1} \mathrm{OVER}^{\mathrm{F}}+\alpha_{2} \mathrm{REQ}^{\mathrm{F}}+\alpha_{3}^{\mathrm{F}} \mathrm{UNDER}^{\mathrm{F}}+\ldots \forall \text { females at } \\
\text { education level “ } \mathrm{j} ”, \quad \mathrm{j}=1, \ldots, \mathrm{J},
\end{aligned}
$$

where $\mathbf{J}$ is the number of education categories.

The predictions obtained for each level of education are then averaged, and these averages regressed on the level of education. In this supplementary simple

\footnotetext{
${ }^{7}$ This exposition draws upon Chiswick and Miller (2010a).
} 
regression, each observation is weighted by the number of females with the particular level of education $\left(\mathrm{w}_{\mathrm{j}}\right)$. That is:

${\overline{\ln \mathrm{y}_{\mathrm{j}}}}_{\mathrm{w}_{\mathrm{j}}}=\beta_{0} \mathrm{w}_{\mathrm{j}}+\beta_{1} \mathrm{EDUC}_{\mathrm{j}} \mathrm{w}_{\mathrm{j}}+v_{\mathrm{j}} \mathrm{w}_{\mathrm{j}}$, where $\mathrm{w}_{\mathrm{j}}$ are the weights.

$\beta_{1}$ in this weighted simple regression is an estimate of the return to education for females.

In the second step, the estimated earnings effects from the ORU variables for males can be used to predict earnings for females. Specifically, the predictions are:

$$
\begin{aligned}
\ln \mathrm{y}=\alpha_{0}+\alpha_{1} \mathrm{OVER}^{\mathrm{F}}+\alpha_{2} \mathrm{REQ}^{\mathrm{F}}+\alpha_{3}^{\mathrm{M}} \mathrm{UNDER}^{\mathrm{F}}+\ldots \forall \text { females at } \\
\text { education level “ } \mathrm{j} \text { ”, } \mathrm{j}=1, \ldots, \mathrm{J} .
\end{aligned}
$$

The predictions obtained from (4) are then related to the years of education in the weighted simple regression outlined in equation (3). $\beta_{1}$ in this second supplementary regression is the return to education for females under the assumption that the returns to over education, required education and under education are the same for females and males. Comparison of this return with that obtained using the predictions of equation (2) shows the contribution of the differences in the estimated effects of the ORU variables for males and females to the conventional estimate of the return to education for females.

In the third step, the ORU variables for females are replaced using the sample averages, conditional upon the particular level of education “ $\mathrm{j}$ ”, for males. That is,

$$
\begin{aligned}
\ln \mathrm{y}=\alpha_{0}+\alpha_{1} \overline{\mathrm{OVER}}^{\mathrm{M}}+\alpha_{2}^{\mathrm{M}} \overline{\mathrm{REQ}}^{\mathrm{M}}+\alpha_{3}^{\mathrm{M}}{\overline{\mathrm{UNDER}^{\mathrm{M}}}}^{+\ldots \forall \text { females at }} \\
\text { education level “ } \mathrm{j} ”, \quad \mathrm{j}=1, \ldots, \mathrm{J} .
\end{aligned}
$$

Again, the averages of the predictions at each level of education are regressed on the years of education via the weighted simple regression in equation (3). $\beta_{1}$ in this third supplementary regression is the estimate of the return to education for 
females under the twin assumptions that the returns to the ORU variables for females are the same as for males and the mean values of these variables for females are the same as for males. This simulated return to education can be compared to that obtained in the previous step to show the incremental contribution of differences in values of the ORU variables for females and males to the return to education obtained by females.

The final step in the Chiswick and Miller (2008) procedure involves using the number of males at each level of education for the weighting variable in the supplementary weighted simple regression depicted in equation (3). Following this change, the $\beta_{1}$ obtained from the simple regression will be the estimate of the return to education for males. ${ }^{8}$

Thus, the set of substitutions outlined above progressively move us from the return to education for females to the return to education for males. This enables the roles of matched and mismatched education in the labor market on the return to education to be assessed.

\section{DATA}

The data used in this paper are drawn from the China Health and Nutrition Survey (CHNS). The CHNS is a collaborative project of the National Institute of Nutrition and Food Safety, the Chinese Centre for Disease Control and Prevention, and the University of North Carolina at Chapel Hill. The survey was conducted in 1989, 1991, 1993, 1997, 2000, 2004, and 2006 and covered 9 provinces, namely

\footnotetext{
${ }^{8}$ The order in which the substitutions are undertaken (i.e., whether those in equation (5) are undertaken prior to those in equation (4)) can be changed to assess the importance of path dependence. Similarly, the complete set of substitutions for the over education, required education and under education components of education may be undertaken sequentially, so that only the coefficients and means for over education (or required education or under education) are replaced first, and then this is followed by the replacement of the coefficients and means for a further variable in the ORU specification of the earnings equation. Within any step, the particular substitutions can also be undertaken one at a time.
} 
Guangxi, Guizhou, Heilongjiang, Henan, Hubei, Hunan, Jiangsu, Liaoning and Shandong. ${ }^{9}$ These provinces vary substantially in geography, economic development, public resources, and health indicators. Four counties were selected in each province. In addition, the provincial capital and a lower income city were selected when feasible.

Because of the focus on the returns to education in urban China in this paper, only individuals in urban areas with positive wage and salary earnings are included in the analysis; those who are retired, in school, or working part-time are excluded. Owners of private or individual enterprises have also been excluded, because it is difficult to separate their wages from profit income. Observations with missing values on education, experience, etc. have been dropped.

The earnings measure used in this study is the average monthly regular wages, excluding the earnings of secondary jobs, all kinds of subsidies and annual bonuses, as the latter have the potential to depend on group productivity to a greater extent than they depend on individual productivity. This definition follows Chen and Hamori (2009).

Data for three years are used: 1993, 2004 and 2006. The use of the data for 1993 is based on the timing of the urban reforms. As Zhang et al. (2005, p.732) note, “...urban reforms proceeded very slowly until the middle and late 1990s...". 10 Thus, the analyses of the 1993 data will provide insights into wage determination before the urban wage reforms took effect. The impact of these wage reforms will be captured through study of the data for 2004 and 2006. Chen and Hamori (2009) have recently conducted comprehensive analyses of earnings determination in urban China using CHNS data pooled across 2004 and 2006. As noted above, one of their findings, that

\footnotetext{
${ }^{9}$ The coverage of these provinces has varied slightly over time. In particular, Heilongjiang province was not included in the 1993 survey which is used below.

${ }^{10}$ For an outline of the labor market reforms, see Meng and Kidd (1997) and Knight and Song (2003).
} 
the return to education for males exceeds that for females, contrasts with the typical findings in the literature. The separate analysis of the data for these years will enable further assessment of this unconventional finding.

The CHNS is also used to compile the usual or reference level of education in the ORU model. For this purpose the mean level of education in each occupation is used (see Hartog (2000) on this Realized Matches procedure, and Chiswick and Miller (2010b) for a recent evaluation). The reference level is computed separately for each year of data collection.

\section{EMPIRICAL RESULTS}

The estimating equation used in this analysis is quite standard, and relates the natural logarithm of average monthly earnings to educational attainment (either the actual years of education in the Mincer equation, or variables for required education, over education and under education in the ORU model), potential labor market experience and its square, the natural logarithm of the usual hours worked, marital status, rural registration, ownership type of the enterprise where employed, and, in some specifications, location of residence and occupation of employment. Appendix A presents the definitions of all variables.

Table 1 presents information on the mean of the natural logarithm of earnings for males and females in 1993, 2004 and 2006. These data demonstrate the rapid growth in earnings over this time period, that females earn less than males, and that the female earnings disadvantage had widened over time, from 17 percent in 1993 to 20 percent in 2004 and 24 percent in $2006 .{ }^{11}$

\footnotetext{
${ }^{11}$ This evidence for an increase in the female earnings disadvantage is consistent with evidence for earlier time periods, such as the change between 1988 and 1995 documented in Yang (2005).
} 
Table 1

Mean Natural Logarithm of Earnings for Males and Females in 1993, 2004 and 2006

\begin{tabular}{lcccccc}
\hline & \multicolumn{3}{c}{ Males } & & Females \\
\cline { 2 - 7 } & 1993 & 2004 & 2006 & 1993 & 2004 & 2006 \\
\hline Mean Earnings & 5.114 & 6.771 & 6.989 & 4.944 & 6.571 & 6.749 \\
\hline Source: China Health and Nutrition Survey, 1993,2004 and 2006.
\end{tabular}

The regression analyses of the determinants of these earnings is based on three models. The first model is for a restricted specification that includes only personal and enterprise-type variables. The second model includes variables for region of residence, while the third model also contains variables for occupation of employment. Separate equations are estimated for males and females.

\section{(i) $\quad$ Mincer equation results}

1993

Table 2 presents the estimated coefficients obtained from applying a standard education and experience model to urban areas in 1993. The adjusted $\mathrm{R}^{2}$ in these estimations are all around 0.19 , which is reasonable for a cross-sectional estimation of an earnings equation. Five of the eight slope coefficients in specification (i) are statistically significant at conventional levels for males, as are six of the eight slope coefficients for females. The Table 2 results mirror quite well what is known about the return to education in China around this period. First, the return to education is quite low, for both males and females. Second, the return to education for males is less than that for females. Indeed, in several of the specifications, the return to education for males is statistically insignificant. Meng (1998) also reported that the 
return to education for males was statistically insignificant in rural China in the late 1980s.

Table 2

\section{Estimates of Mincerian Model of Earnings Determination in Urban Areas, 1993}

\begin{tabular}{|c|c|c|c|c|c|c|}
\hline \multirow{2}{*}{ Variables } & \multicolumn{3}{|c|}{ Males } & \multicolumn{3}{|c|}{ Females } \\
\hline & (i) & (ii) & (iii) & (iv) & (v) & (vi) \\
\hline Constant & $\begin{array}{c}3.590 * * * \\
(9.88)\end{array}$ & $\begin{array}{c}3.572 * * * \\
(9.71)\end{array}$ & $\begin{array}{c}3.606^{* * *} * \\
(9.51)\end{array}$ & $\begin{array}{c}3.686 * * * \\
(10.69)\end{array}$ & $\begin{array}{c}3.753 * * * \\
(10.70)\end{array}$ & $\begin{array}{c}3.827 * * * \\
(11.67)\end{array}$ \\
\hline $\begin{array}{l}\text { Years of } \\
\text { Education }\end{array}$ & $\begin{array}{c}0.012^{*} \\
(1.94)\end{array}$ & $\begin{array}{l}0.009 \\
(1.43)\end{array}$ & $\begin{array}{l}0.008 \\
(0.97)\end{array}$ & $\begin{array}{c}0.022 * * * \\
(3.74)\end{array}$ & $\begin{array}{c}0.023 * * * \\
(3.76)\end{array}$ & $\begin{array}{c}0.020^{* *} \\
(2.55)\end{array}$ \\
\hline Log hours & $\begin{array}{c}0.305 * * * \\
(3.16)\end{array}$ & $\begin{array}{c}0.292 * * * \\
(3.04)\end{array}$ & $\begin{array}{c}0.281 * * * \\
(2.88)\end{array}$ & $\begin{array}{c}0.190 * * \\
(2.16)\end{array}$ & $\begin{array}{c}0.177^{* *} \\
(2.00)\end{array}$ & $\begin{array}{c}0.161 * \\
(1.91)\end{array}$ \\
\hline $\begin{array}{l}\text { Experience } \\
\text { (Exp) }\end{array}$ & $\begin{array}{c}0.021 * * \\
(2.16)\end{array}$ & $\begin{array}{c}0.022 * * \\
(2.18)\end{array}$ & $\begin{array}{c}0.022 * * \\
(2.19)\end{array}$ & $\begin{array}{c}0.033 * * * \\
(3.51)\end{array}$ & $\begin{array}{c}0.033 * * * \\
(3.55)\end{array}$ & $\begin{array}{c}0.032 * * * \\
(3.46)\end{array}$ \\
\hline $\operatorname{Exp}^{2} / 100$ & $\begin{array}{l}-0.026 \\
(1.53)\end{array}$ & $\begin{array}{l}-0.028 \\
(1.63)\end{array}$ & $\begin{array}{c}-0.029 * \\
(1.68)\end{array}$ & $\begin{array}{c}-0.053 * * * \\
(2.85)\end{array}$ & $\begin{array}{c}-0.053 * * * \\
(2.88)\end{array}$ & $\begin{array}{c}-0.052 * * * \\
(2.87)\end{array}$ \\
\hline Married & $\begin{array}{l}0.136 \\
(1.35)\end{array}$ & $\begin{array}{l}0.140 \\
(1.35)\end{array}$ & $\begin{array}{l}0.126 \\
(1.22)\end{array}$ & $\begin{array}{l}-0.020 \\
(0.26)\end{array}$ & $\begin{array}{l}-0.015 \\
(0.19)\end{array}$ & $\begin{array}{l}-0.008 \\
(0.10)\end{array}$ \\
\hline $\begin{array}{l}\text { Rural } \\
\text { Registration }\end{array}$ & $\begin{array}{l}-0.090 \\
(1.29)\end{array}$ & $\begin{array}{l}-0.081 \\
(1.17)\end{array}$ & $\begin{array}{l}-0.076 \\
(1.10)\end{array}$ & $\begin{array}{l}-0.031 \\
(0.44)\end{array}$ & $\begin{array}{l}-0.032 \\
(0.47)\end{array}$ & $\begin{array}{l}-0.032 \\
(0.46)\end{array}$ \\
\hline State & $\begin{array}{c}-0.312 * * * \\
(6.01)\end{array}$ & $\begin{array}{c}-0.292 * * * \\
(5.42)\end{array}$ & $\begin{array}{c}-0.297 * * * \\
(5.43)\end{array}$ & $\begin{array}{c}-0.169 * * * \\
(3.55)\end{array}$ & $\begin{array}{c}-0.164 * * * \\
(3.58)\end{array}$ & $\begin{array}{c}-0.176^{* * *} \\
(3.85)\end{array}$ \\
\hline Private & $\begin{array}{c}0.481 * * * \\
(3.46)\end{array}$ & $\begin{array}{c}0.506^{* * * *} \\
(3.62)\end{array}$ & $\begin{array}{c}0.509 * * * \\
(3.55)\end{array}$ & $\begin{array}{c}0.746 * * * \\
(4.76)\end{array}$ & $\begin{array}{c}0.751 * * * \\
(4.70)\end{array}$ & $\begin{array}{c}0.734 * * * \\
(4.76)\end{array}$ \\
\hline Central & & $\begin{array}{l}0.071 \\
(1.13)\end{array}$ & $\begin{array}{l}0.061 \\
(0.95)\end{array}$ & & $\begin{array}{l}-0.051 \\
(0.87)\end{array}$ & $\begin{array}{l}-0.058 \\
(0.97)\end{array}$ \\
\hline East & & $\begin{array}{l}0.116 \\
(1.95)\end{array}$ & $\begin{array}{l}0.112^{*} \\
(1.84)\end{array}$ & & $\begin{array}{l}-0.006 \\
(0.10)\end{array}$ & $\begin{array}{l}-0.012 \\
(0.20)\end{array}$ \\
\hline Clerk & & & $\begin{array}{l}-0.027 \\
(0.38)\end{array}$ & & & $\begin{array}{l}0.056 \\
(0.70)\end{array}$ \\
\hline Senior & & & $\begin{array}{l}0.030 \\
(0.36)\end{array}$ & & & $\begin{array}{l}-0.007 \\
(0.10)\end{array}$ \\
\hline Junior & & & $\begin{array}{l}0.064 \\
(1.16)\end{array}$ & & & $\begin{array}{l}0.061 \\
(1.25)\end{array}$ \\
\hline Leader & & & $\begin{array}{l}0.122 \\
(1.37)\end{array}$ & & & $\begin{array}{c}0.255^{*} \\
(1.80)\end{array}$ \\
\hline Other & & & $\begin{array}{l}0.154 \\
(0.84)\end{array}$ & & & $\begin{array}{c}0.408^{* *} \\
(2.12)\end{array}$ \\
\hline Adj. $R^{2}$ & 0.189 & 0.191 & 0.191 & 0.186 & 0.185 & 0.196 \\
\hline Sample size & 683 & 683 & 683 & 547 & 547 & 547 \\
\hline
\end{tabular}

Notes: Numbers in parentheses are absolute values of heteroskedasticity-consistent ' $t$ ' statistics; * denotes that the variable is significant at the $10 \%$ level; ** denotes that the variable is significant at the $5 \%$ level; *** denotes that the variable is significant at the $1 \%$ level. See the Appendix for definitions of variables.

Source: China Health and Nutrition Survey, 1993. 
Third, the return to education tends to fall as controls for additional variables are added to the specification. These additional control variables show a positive, though weak, association between earnings and hours worked, and that earnings increase at a decreasing rate with potential labor market experience. Similar to the payoff structure for educational attainment, the gains in earnings associated with additional years of labor market experience for females are typically greater than those for males. Hence, evaluated at 5 years of experience, the payoff to an extra year of experience is 2.8 percent for females and 1.8 percent for males. At 10 years of experience the payoff to an extra year of experience is 2.2 percent for females and 1.6 percent for males, and at 20 years of experience the payoff to an extra year of experience is just 1.2 percent for females and 1.1 percent for males. The Table 2 results also reveal that earnings are relatively high in the small number of privatelyrun enterprises and relatively low in state-owned enterprises. The models presented in columns (ii) and (iii) show that in this early period of the urban wage reform process, there was limited variation in earnings across regions of residence and occupations.

There is one result in Table 2 that appears anomalous, namely for the link between hours of work and earnings. The hours worked variable is significant, but has a small coefficient. In the analyses for 2004 and 2006 that follow, the hours worked variable is statistically insignificant. This finding appears to be due to the reference points for earnings and hours worked in the survey differing: The monthly earnings data refer to the average monthly earnings across the past year, whereas the hours worked data refer only to the past week.

\section{$\underline{2004}$}

Table 3 lists estimates of the models of earnings determination based on the 2004 data. The structure of this table is the same as that used for the analyses of the 
1993 data. The Table 3 results reveal that the post-reform urban labor market in China is characterized by higher returns to education for both males and females. Moreover, the gap between the return to education for males and females has widened over the period reviewed: in 2004 it was 3.7 percentage points (column (ii) model) compared to the more modest 1.3 percentage points in 1993. This is consistent with the evidence from studies of other data sets documented in Section II. Associated with this increase in the importance of education to earnings determination in urban China has been a decrease in the importance of potential labor market experience (or seniority) for both males and females. The potential labor market experience variables are statistically insignificant in the model for males, and the increase in earnings with labor market experience for females is only around one-half of that recorded in the data for 1993.

The wage reforms in the urban Chinese labor market also appear to have been associated with an increase in the spread of earnings across occupations. Thus, whereas the occupation of employment played a quite minor role in earnings determination in 1993, there was a difference of around 33 percentage points between the least-paying and highest-paying occupations in 2004. Moreover, the inclusion of the variables for occupation of employment in the estimating equation is associated with a material increase in the adjusted $\mathrm{R}^{2}$, particularly among males. In the case of the 1993 data, the addition of the variables for occupation of employment did not lead to any change in the adjusted $\mathrm{R}^{2}$ for males.

In summary, the comparisons between 1993 and 2004 suggest that the wage reforms in the urban labor market are linked with greater rewards to formal education and to employment in senior occupations, and with a dissipation of the earnings increases associated with potential labor market experience. In the 2004 CHNS the 
return to education for females was up to four percentage points greater than that for males.

Table 3

\section{Estimates of Mincerian Model of Earnings Determination in Urban Areas, 2004}

\begin{tabular}{|c|c|c|c|c|c|c|}
\hline \multirow[b]{2}{*}{ Variables } & \multicolumn{3}{|c|}{ Males } & \multicolumn{3}{|c|}{ Females } \\
\hline & (i) & (ii) & (iii) & (iv) & (v) & (vi) \\
\hline Constant & $\begin{array}{c}5.759 * * * \\
(13.96)\end{array}$ & $\begin{array}{c}5.672 * * * * \\
(13.98)\end{array}$ & $\begin{array}{c}5.486 * * * \\
(13.43)\end{array}$ & $\begin{array}{c}5.027 * * * \\
(9.97)\end{array}$ & $\begin{array}{c}4.796^{* * * *} \\
(9.42)\end{array}$ & $\begin{array}{c}4.790 * * * \\
(9.90)\end{array}$ \\
\hline $\begin{array}{l}\text { Years of } \\
\text { Education }\end{array}$ & $\begin{array}{c}0.047 * * * \\
(5.77)\end{array}$ & $\begin{array}{c}0.050 * * * * \\
(6.01)\end{array}$ & $\begin{array}{c}0.031 * * * \\
(3.38)\end{array}$ & $\begin{array}{c}0.087 * * * \\
(7.92)\end{array}$ & $\begin{array}{c}0.087 * * * \\
(8.10)\end{array}$ & $\begin{array}{c}0.070^{* * * *} \\
(5.57)\end{array}$ \\
\hline Log hours & $\begin{array}{l}0.025 \\
(0.25)\end{array}$ & $\begin{array}{l}0.023 \\
(0.23)\end{array}$ & $\begin{array}{l}0.079 \\
(0.79)\end{array}$ & $\begin{array}{l}0.021 \\
(0.18)\end{array}$ & $\begin{array}{l}0.011 \\
(0.10)\end{array}$ & $\begin{array}{l}0.040 \\
(0.36)\end{array}$ \\
\hline $\begin{array}{l}\text { Experience } \\
\text { (Exp) }\end{array}$ & $\begin{array}{l}0.003 \\
(0.26)\end{array}$ & $\begin{array}{l}0.005 \\
(0.45)\end{array}$ & $\begin{array}{l}0.004 \\
(0.42)\end{array}$ & $\begin{array}{c}0.018^{*} \\
(1.85)\end{array}$ & $\begin{array}{c}0.023 * * \\
(2.44)\end{array}$ & $\begin{array}{c}0.025^{* * *} * \\
(2.65)\end{array}$ \\
\hline $\operatorname{Exp}^{2} / 100$ & $\begin{array}{l}0.001 \\
(0.04)\end{array}$ & $\begin{array}{c}-0.003 \\
(0.14)\end{array}$ & $\begin{array}{c}-0.006 \\
(0.34)\end{array}$ & $\begin{array}{l}-0.027 \\
(1.23)\end{array}$ & $\begin{array}{c}-0.039^{*} \\
(1.74)\end{array}$ & $\begin{array}{c}-0.047 * * \\
(2.15)\end{array}$ \\
\hline Married & $\begin{array}{c}0.260 * * * \\
(3.10)\end{array}$ & $\begin{array}{c}0.255^{* * *} * \\
(3.10)\end{array}$ & $\begin{array}{c}0.219 * * * \\
(2.69)\end{array}$ & $\begin{array}{c}0.123^{*} \\
(1.68)\end{array}$ & $\begin{array}{l}0.090 \\
(1.23)\end{array}$ & $\begin{array}{l}0.076 \\
(1.04)\end{array}$ \\
\hline $\begin{array}{l}\text { Rural } \\
\text { Registration }\end{array}$ & $\begin{array}{c}-0.136^{* *} \\
(2.05)\end{array}$ & $\begin{array}{l}-0.104 \\
(1.52)\end{array}$ & $\begin{array}{l}-0.073 \\
(1.06)\end{array}$ & $\begin{array}{l}-0.011 \\
(0.10)\end{array}$ & $\begin{array}{l}0.032 \\
(0.30)\end{array}$ & $\begin{array}{l}0.047 \\
(0.44)\end{array}$ \\
\hline State & $\begin{array}{c}0.121 * * \\
(2.08)\end{array}$ & $\begin{array}{c}0.147 * * \\
(2.51)\end{array}$ & $\begin{array}{c}0.161 * * * \\
(2.73)\end{array}$ & $\begin{array}{c}0.179 * * \\
(2.31)\end{array}$ & $\begin{array}{c}0.214 * * * \\
(2.81)\end{array}$ & $\begin{array}{c}0.189 * * \\
(2.44)\end{array}$ \\
\hline Private & $\begin{array}{c}0.181 * * * \\
(2.58)\end{array}$ & $\begin{array}{c}0.174 * * \\
(2.46)\end{array}$ & $\begin{array}{c}0.232 * * * \\
(3.31)\end{array}$ & $\begin{array}{c}0.271 * * * \\
(2.98)\end{array}$ & $\begin{array}{c}0.280 * * * \\
(3.20)\end{array}$ & $\begin{array}{c}0.292 * * * \\
(3.42)\end{array}$ \\
\hline Central & & $\begin{array}{c}-0.014 \\
(0.25)\end{array}$ & $\begin{array}{l}-0.003 \\
(0.05)\end{array}$ & & $\begin{array}{c}0.211 * * * \\
(3.11)\end{array}$ & $\begin{array}{c}0.198 * * * \\
(2.99)\end{array}$ \\
\hline East & & $\begin{array}{c}0.103 * \\
(1.64)\end{array}$ & $\begin{array}{c}0.141 * * \\
(2.28)\end{array}$ & & $\begin{array}{c}0.290 * * * \\
(4.42)\end{array}$ & $\begin{array}{c}0.306 * * * \\
(4.79)\end{array}$ \\
\hline Clerk & & & $\begin{array}{c}0.252^{* * * *} \\
(3.16)\end{array}$ & & & $\begin{array}{c}0.196^{* *} \\
(2.53)\end{array}$ \\
\hline Senior & & & $\begin{array}{c}0.369 * * * \\
(4.21)\end{array}$ & & & $\begin{array}{c}0.363^{* * *} \\
(3.60)\end{array}$ \\
\hline Junior & & & $\begin{array}{c}0.189 * * * \\
(2.98)\end{array}$ & & & $\begin{array}{c}0.153^{* *} \\
(2.14)\end{array}$ \\
\hline Leader & & & $\begin{array}{c}0.331 * * * \\
(4.38)\end{array}$ & & & $\begin{array}{l}0.095 \\
(0.95)\end{array}$ \\
\hline Other & & & $\begin{array}{c}0.182 * \\
(1.82)\end{array}$ & & & $\begin{array}{l}0.108 \\
(0.83)\end{array}$ \\
\hline Adj. $R^{2}$ & 0.117 & 0.123 & 0.153 & 0.187 & 0.212 & 0.228 \\
\hline Sample size & 512 & 512 & 512 & 404 & 404 & 404 \\
\hline
\end{tabular}

Notes: Numbers in parentheses are absolute values of heteroskedasticity-consistent ' $t$ ' statistics; * denotes that the variable is significant at the $10 \%$ level; ** denotes that the variable is significant at the $5 \%$ level; *** denotes that the variable is significant at the $1 \%$ level. See the Appendix for definitions of variables.

Source: China Health and Nutrition Survey, 2004. 
Table 4 contains the analyses for 2006. The main result from these estimations is that, unlike most literature in this area, though consistent with Chen and Hamori (2009), the return to education for males in urban areas, at 7.5 percent, is very similar to that for females, 7.4 percent (column (ii) specification). This finding, that men and women receive similar returns to education in China's urban areas, contrasts with the result in Ren and Miller (2011) from analysis of the rural component of the same data set. Ren and Miller (2011) report that in rural China, the return to education is 7.2 for women and 3.8 for men. The Table 4 evidence for 2006 also contrasts with the findings for 2004, reported above. The current finding, of broad equality between the estimates of the return to education for men and women in urban China using the 2006 wave of the CHNS, shows that the result of Chen and Hamori (2009), which was based on data pooled across the 2004 and 2006 waves, is driven by the most recent wave of data collection.

Compared to 2004, the broad equality of the return to education for males and females has emerged due to an increase in the return to education for males of several percentage points over this period, and a decline in the return to education for females of one percentage point. According to Zhang et al. (2005), the return to education for males increased by two-to-three percentage points in the space of only two years during 1992-1994 and 1997-1999, so changes of this magnitude for males are not unusual. However, during these periods, the return to education for females also increased markedly, with both sets of changes being attributed to the economic reform process (Zhang et al., 2005, p.746). Hence, the distinguishing feature of the current set of analyses is the decline in the return to education for females. Study of changes in the returns to education in rural China between 2004 and 2006 using the same data set reveals similar changes, although the decline for females is more modest. 
Table 4

Estimates of Mincerian Model of Earnings Determination in Urban Areas, 2006

\begin{tabular}{|c|c|c|c|c|c|c|}
\hline \multirow{2}{*}{ Variables } & \multicolumn{3}{|c|}{ Males } & \multicolumn{3}{|c|}{ Females } \\
\hline & (i) & (ii) & (iii) & (iv) & (v) & (vi) \\
\hline Constant & $\begin{array}{c}5.742 * * * \\
(17.22)\end{array}$ & $\begin{array}{c}5.591 * * * \\
(16.86)\end{array}$ & $\begin{array}{c}5.685 * * * \\
(18.29)\end{array}$ & $\begin{array}{c}5.545^{* * * *} \\
(10.98)\end{array}$ & $\begin{array}{c}5.347 * * * \\
(10.57)\end{array}$ & $\begin{array}{c}5.385 * * * \\
(10.71)\end{array}$ \\
\hline $\begin{array}{l}\text { Years of } \\
\text { Education }\end{array}$ & $\begin{array}{c}0.075^{* * * *} \\
(8.12)\end{array}$ & $\begin{array}{c}0.075^{* * * *} \\
(8.06)\end{array}$ & $\begin{array}{c}0.056^{* * * *} \\
(5.75)\end{array}$ & $\begin{array}{c}0.072 * * * \\
(7.45)\end{array}$ & $\begin{array}{c}0.074 * * * \\
(7.58)\end{array}$ & $\begin{array}{c}0.052 * * * \\
\quad(4.85)\end{array}$ \\
\hline Log hours & $\begin{array}{l}-0.045 \\
(0.58)\end{array}$ & $\begin{array}{l}-0.060 \\
(0.76)\end{array}$ & $\begin{array}{l}-0.044 \\
(0.60)\end{array}$ & $\begin{array}{l}0.009 \\
(0.07)\end{array}$ & $\begin{array}{l}-0.004 \\
(0.04)\end{array}$ & $\begin{array}{l}0.022 \\
(0.17)\end{array}$ \\
\hline $\begin{array}{l}\text { Experience } \\
\text { (Exp) }\end{array}$ & $\begin{array}{c}0.020 * \\
(1.79)\end{array}$ & $\begin{array}{c}0.020^{*} \\
(1.76)\end{array}$ & $\begin{array}{l}0.018 \\
(1.60)\end{array}$ & $\begin{array}{l}0.004 \\
(0.40)\end{array}$ & $\begin{array}{l}0.010 \\
(0.87)\end{array}$ & $\begin{array}{l}0.012 \\
(0.99)\end{array}$ \\
\hline $\operatorname{Exp}^{2} / 100$ & $\begin{array}{l}-0.027 \\
(1.24)\end{array}$ & $\begin{array}{l}-0.024 \\
(1.13)\end{array}$ & $\begin{array}{l}-0.026 \\
(1.25)\end{array}$ & $\begin{array}{l}0.009 \\
(0.48)\end{array}$ & $\begin{array}{l}-0.000 \\
(0.02)\end{array}$ & $\begin{array}{l}-0.011 \\
(0.56)\end{array}$ \\
\hline Married & $\begin{array}{l}0.065 \\
(0.73)\end{array}$ & $\begin{array}{l}0.040 \\
(0.45)\end{array}$ & $\begin{array}{l}0.014 \\
(0.16)\end{array}$ & $\begin{array}{l}-0.108 \\
(0.89)\end{array}$ & $\begin{array}{l}-0.148 \\
(1.18)\end{array}$ & $\begin{array}{l}-0.171 \\
(1.35)\end{array}$ \\
\hline $\begin{array}{l}\text { Rural } \\
\text { Registration }\end{array}$ & $\begin{array}{l}-0.037 \\
(0.46)\end{array}$ & $\begin{array}{l}0.015 \\
(0.18)\end{array}$ & $\begin{array}{l}0.014 \\
(0.17)\end{array}$ & $\begin{array}{l}0.072 \\
(0.94)\end{array}$ & $\begin{array}{l}0.112 \\
(1.36)\end{array}$ & $\begin{array}{l}0.114 \\
(1.37)\end{array}$ \\
\hline State & $\begin{array}{c}0.248 * * * \\
(3.42)\end{array}$ & $\begin{array}{c}0.277 * * * \\
(3.84)\end{array}$ & $\begin{array}{c}0.266^{* * * *} \\
(3.56)\end{array}$ & $\begin{array}{l}0.411 * * * \\
\quad(6.25)\end{array}$ & $\begin{array}{c}0.427 * * * \\
\quad(6.04)\end{array}$ & $\begin{array}{c}0.396 * * * \\
(5.21)\end{array}$ \\
\hline Private & $\begin{array}{c}0.296 * * * \\
(4.05)\end{array}$ & $\begin{array}{c}0.300 * * * \\
(4.21)\end{array}$ & $\begin{array}{c}0.343 * * * \\
(4.64)\end{array}$ & $\begin{array}{c}0.242 * * * \\
(3.44)\end{array}$ & $\begin{array}{c}0.253 * * * \\
(3.52)\end{array}$ & $\begin{array}{c}0.284 * * * \\
(3.70)\end{array}$ \\
\hline Central & & $\begin{array}{c}0.214 * * * \\
(2.79)\end{array}$ & $\begin{array}{c}0.207 * * * \\
(2.86)\end{array}$ & & $\begin{array}{c}0.179 * * * \\
(2.70)\end{array}$ & $\begin{array}{c}0.176 * * * \\
\quad(2.74)\end{array}$ \\
\hline East & & $\begin{array}{c}0.243 * * * \\
(2.99)\end{array}$ & $\begin{array}{c}0.234 * * * \\
(2.98)\end{array}$ & & $\begin{array}{c}0.224 * * * \\
(2.58)\end{array}$ & $\begin{array}{c}0.225 * * * \\
\quad(2.73)\end{array}$ \\
\hline Clerk & & & $\begin{array}{l}0.060 \\
(0.77)\end{array}$ & & & $\begin{array}{l}0.264 \\
(2.73)\end{array}$ \\
\hline Senior & & & $\begin{array}{c}0.319 * * * \\
(3.73)\end{array}$ & & & $\begin{array}{c}0.395 * * * \\
(4.25)\end{array}$ \\
\hline Junior & & & $\begin{array}{l}0.107 \\
(1.62)\end{array}$ & & & $\begin{array}{c}0.172 * * * \\
\quad(2.70)\end{array}$ \\
\hline Leader & & & $\begin{array}{c}0.372 * * * \\
(4.12)\end{array}$ & & & $\begin{array}{c}0.249 * * * \\
(2.84)\end{array}$ \\
\hline Other & & & $\begin{array}{l}0.064 \\
(0.47)\end{array}$ & & & $\begin{array}{l}0.166 \\
(0.85)\end{array}$ \\
\hline Adj. $R^{2}$ & 0.157 & 0.170 & 0.200 & 0.228 & 0.239 & 0.264 \\
\hline Sample size & 536 & 536 & 536 & 404 & 404 & 404 \\
\hline
\end{tabular}

Notes: Numbers in parentheses are absolute values of heteroskedasticity-consistent ' $t$ ' statistics; * denotes that the variable is significant at the $10 \%$ level; ** denotes that the variable is significant at the $5 \%$ level; *** denotes that the variable is significant at the $1 \%$ level. See the Appendix for definitions of variables.

Source: China Health and Nutrition Survey, 2006.

The decline in the return to schooling for females documented here could be a reflection of the recent growth in the number of female graduates. Females comprised 48.9 percent of all undergraduates in 2006 , and 44.5 percent of all masters students in 
that year (Tan and Jiang, 2008). These changes will have largely negated the lower relative supply of highly skilled women compared to men argument advanced as an explanation for the conventional finding of a higher return to schooling for females than for males in the study of the Chinese labor market (see Li, 2003). However, study of data collections for more recent periods will be needed to confirm this.

The links between the gender differential in the returns to education in the labor market of contemporary urban China and the incidence and earnings effects of matched and mismatched education is investigated below. ${ }^{12}$ This is done using the ORU earnings equation (see Hartog, 2000) and the decomposition developed by Chiswick and Miller (2008).

(ii) Returns to over education, required education and under education

The specification of the ORU model adopted in this section is the same as that used for the Mincer equation, other than for the use of three variables, for the years of required level of education, and any years of either over education or under education, in place of the single variable for the worker's actual years of education in the Mincer model. $^{13}$

\section{$\underline{1993}$}

The main interest in the Table 5 results rests with the three variables that are unique to the ORU specification, and hence the discussion will focus on the estimated effects for these variables. It is noted, however, that the use of the variables for years of over, required and under education in place of the conventional measure for years

\footnotetext{
${ }^{12}$ See Miller and Ren (2011) for detailed study of the incidence of matched and mismatched education in China in 1993 and 2006.

${ }^{13}$ As the required level of education is compiled using data disaggregated to a finer level than the five occupations used in the specification of column (iii), both the required education variable and the occupation variables can be used in the one estimating equation.
} 
of actual education is not associated with any major change in the estimated effects of the other variables included in the estimating equation.

Table 5

Estimates of ORU Model of Earnings Determination in Urban Areas, 1993

\begin{tabular}{|c|c|c|c|c|c|c|}
\hline \multirow{2}{*}{ Variables } & \multicolumn{3}{|c|}{ Males } & \multicolumn{3}{|c|}{ Females } \\
\hline & (i) & (ii) & (iii) & (iv) & (v) & (vi) \\
\hline Constant & $\begin{array}{c}3.473 * * * \\
(9.42)\end{array}$ & $\begin{array}{c}3.454 * * * \\
(9.26)\end{array}$ & $\begin{array}{c}3.264 * * * \\
(7.84)\end{array}$ & $\begin{array}{c}3.691 * * * \\
(10.40)\end{array}$ & $\begin{array}{c}3.755 * * * \\
(10.53)\end{array}$ & $\begin{array}{c}3.897 * * * \\
(10.59)\end{array}$ \\
\hline $\begin{array}{l}\text { Reference } \\
\text { Education }\end{array}$ & $\begin{array}{c}0.023^{*} \\
(1.68)\end{array}$ & $\begin{array}{l}0.020 \\
(1.46)\end{array}$ & $\begin{array}{l}0.053 \\
(1.57)\end{array}$ & $\begin{array}{c}0.023 * * \\
(2.01)\end{array}$ & $\begin{array}{c}0.025 * * \\
(2.10)\end{array}$ & $\begin{array}{l}0.010 \\
(0.37)\end{array}$ \\
\hline $\begin{array}{l}\text { Over } \\
\text { Education }\end{array}$ & $\begin{array}{l}0.022 \\
(1.53)\end{array}$ & $\begin{array}{l}0.019 \\
(1.33)\end{array}$ & $\begin{array}{l}0.021 \\
(1.43)\end{array}$ & $\begin{array}{l}0.017 \\
(1.32)\end{array}$ & $\begin{array}{l}0.016 \\
(1.23)\end{array}$ & $\begin{array}{l}0.013 \\
(0.97)\end{array}$ \\
\hline $\begin{array}{l}\text { Under } \\
\text { Education }\end{array}$ & $\begin{array}{l}0.015 \\
(1.01)\end{array}$ & $\begin{array}{l}0.018 \\
(1.18)\end{array}$ & $\begin{array}{l}0.016 \\
(1.08)\end{array}$ & $\begin{array}{c}-0.026^{* *} \\
(2.01)\end{array}$ & $\begin{array}{c}-0.026^{* *} \\
(2.04)\end{array}$ & $\begin{array}{c}-0.026^{* *} \\
(2.02)\end{array}$ \\
\hline Log hours & $\begin{array}{c}0.301 * * * \\
(3.07)\end{array}$ & $\begin{array}{c}0.288 * * * \\
(2.96)\end{array}$ & $\begin{array}{c}0.274 * * * \\
(2.80)\end{array}$ & $\begin{array}{c}0.192 * * \\
(2.17)\end{array}$ & $\begin{array}{c}0.178 * * \\
(2.01)\end{array}$ & $\begin{array}{c}0.166^{* *} \\
(1.97)\end{array}$ \\
\hline $\begin{array}{l}\text { Experience } \\
\text { (Exp) }\end{array}$ & $\begin{array}{c}0.023 * * \\
(2.28)\end{array}$ & $\begin{array}{c}0.024 * * \\
(2.31)\end{array}$ & $\begin{array}{c}0.025 * * \\
(2.38)\end{array}$ & $\begin{array}{c}0.032 * * * \\
(3.33)\end{array}$ & $\begin{array}{c}0.032 * * * \\
(3.37)\end{array}$ & $\begin{array}{c}0.031 * * * \\
(3.27)\end{array}$ \\
\hline $\operatorname{Exp}^{2} / 100$ & $\begin{array}{c}-0.033^{*} \\
(1.87)\end{array}$ & $\begin{array}{c}-0.035^{* *} \\
(1.97)\end{array}$ & $\begin{array}{c}-0.035^{* *} \\
(1.99)\end{array}$ & $\begin{array}{c}-0.051 * * * \\
(2.63)\end{array}$ & $\begin{array}{c}-0.051 * * * \\
(2.68)\end{array}$ & $\begin{array}{c}-0.049 * * * \\
(2.62)\end{array}$ \\
\hline Married & $\begin{array}{l}0.131 \\
(1.27)\end{array}$ & $\begin{array}{l}0.134 \\
(1.27)\end{array}$ & $\begin{array}{l}0.119 \\
(1.14)\end{array}$ & $\begin{array}{l}-0.018 \\
(0.23)\end{array}$ & $\begin{array}{l}-0.012 \\
(0.15)\end{array}$ & $\begin{array}{r}-0.005 \\
(0.06)\end{array}$ \\
\hline $\begin{array}{l}\text { Rural } \\
\text { Registration }\end{array}$ & $\begin{array}{l}-0.095 \\
(1.36)\end{array}$ & $\begin{array}{l}-0.086 \\
(1.23)\end{array}$ & $\begin{array}{l}-0.081 \\
(1.17)\end{array}$ & $\begin{array}{l}-0.031 \\
(0.45)\end{array}$ & $\begin{array}{l}-0.034 \\
(0.49)\end{array}$ & $\begin{array}{l}-0.031 \\
(0.45)\end{array}$ \\
\hline State & $\begin{array}{c}-0.315^{* * * *} \\
(6.04)\end{array}$ & $\begin{array}{c}-0.296 * * * \\
(5.47)\end{array}$ & $\begin{array}{c}-0.295 * * * \\
(5.43)\end{array}$ & $\begin{array}{c}-0.169 * * * \\
(3.53)\end{array}$ & $\begin{array}{c}-0.165^{* * * *} \\
(3.61)\end{array}$ & $\begin{array}{c}-0.170 * * * \\
(3.69)\end{array}$ \\
\hline Private & $\begin{array}{c}0.504 * * * \\
(3.53)\end{array}$ & $\begin{array}{c}0.528 * * * \\
(3.67)\end{array}$ & $\begin{array}{c}0.546^{* * * *} \\
(3.77)\end{array}$ & $\begin{array}{l}0.750 * * * \\
\quad(4.67)\end{array}$ & $\begin{array}{c}0.758 * * * \\
(4.62)\end{array}$ & $\begin{array}{c}0.733 * * * \\
(4.68)\end{array}$ \\
\hline Central & & $\begin{array}{l}0.073 \\
(1.18)\end{array}$ & $\begin{array}{l}0.070 \\
(1.12)\end{array}$ & & $\begin{array}{l}-0.054 \\
(0.90)\end{array}$ & $\begin{array}{l}-0.058 \\
(0.96)\end{array}$ \\
\hline East & & $\begin{array}{c}0.115^{*} \\
(1.94)\end{array}$ & $\begin{array}{c}0.114 * \\
(1.87)\end{array}$ & & $\begin{array}{l}-0.006 \\
(0.11)\end{array}$ & $\begin{array}{l}-0.010 \\
(0.16)\end{array}$ \\
\hline Clerk & & & $\begin{array}{l}-0.143 \\
(1.37)\end{array}$ & & & $\begin{array}{l}0.077 \\
(0.73)\end{array}$ \\
\hline Senior & & & $\begin{array}{l}-0.217 \\
(1.24)\end{array}$ & & & $\begin{array}{l}0.036 \\
(0.24)\end{array}$ \\
\hline Junior & & & $\begin{array}{l}-0.007 \\
(0.10)\end{array}$ & & & $\begin{array}{l}0.077 \\
(1.03)\end{array}$ \\
\hline Leader & & & $\begin{array}{l}-0.018 \\
(0.16)\end{array}$ & & & $\begin{array}{c}0.280 * \\
(1.91)\end{array}$ \\
\hline Other & & & $\begin{array}{l}0.164 \\
(0.89)\end{array}$ & & & $\begin{array}{c}0.404 * * \\
(2.11)\end{array}$ \\
\hline Adj. $R^{2}$ & 0.191 & 0.193 & 0.194 & 0.183 & 0.182 & 0.194 \\
\hline Sample size & 683 & 683 & 683 & 547 & 547 & 547 \\
\hline
\end{tabular}

Notes: Numbers in parentheses are absolute values of heteroskedasticity-consistent ' $t$ ' statistics; * denotes that the variable is significant at the $10 \%$ level; ** denotes that the variable is significant at the $5 \%$ level; *** denotes that the variable is significant at the $1 \%$ level. See the Appendix for definitions of variables.

Source: China Health and Nutrition Survey, 1993. 
Each year of education that is usual for the occupation in which the worker is employed is associated with a modest 2.5 percent increase in earnings among females, but the reference level of education is not associated with statistically significant increases in earnings among males (though the point estimate for males is similar to that for females). In other words, for females, the return to education in the conventional education and experience earnings equation for 1993 is around 2.3 percent (Table 2), which is of the same order of magnitude as the return to years of correctly matched education (2.5 percent in Table 5$)$. The return to years of correctly matched education captures the effects on earnings of the acquisition of an extra year of education, and the effects on earnings of moving to an occupation where that extra years of education can be effectively utilized. The similarity of the two returns therefore suggests there was little advantage to correctly matched education in 1993. We return to this theme below.

Similarly, among males the rate of return in the conventional (Mincerian) model is not significantly different from zero, and likewise, the increment in earnings associated with correctly matched education is not significantly different from zero. That is, neither education nor job mobility in order to achieve a better educationoccupation match appears to have been rewarded in the urban Chinese male labor market in 1993.

The variable for years of over education - that is, years of education that are surplus to the usual educational requirements of the occupation in which workers are employed-is not associated with statistically significant increases in earnings in either the estimation for males or that for females (the point estimates are small in each instance, and similar for males and females). The fact that years of surplus education are not rewarded in the labor market will tend to lower the return to 
education in the conventional model, and the similarity of the point estimates indicates that the impact in this regard will be about the same for males and females (see Chiswick and Miller, 2008).

Years of under education - that is, shortfalls in the workers' formal education compared to the levels that are usual in their occupations of employment-are associated with a significant earnings effect only among females. The point estimate of -0.026 for females indicates that low-skilled females who acquire an extra year of education in urban China in 1993 received approximately the same earnings regardless of their occupation of employment. That is, the level of education, but not the education-occupation match, was of some importance among these low-skilled females. A similar, though slightly weaker, pattern characterizes high-skilled females. For males there is a small, positive, but statistically insignificant effect on earnings associated with years of under education. The insignificance of each of the three education variables in the ORU specification of the earnings equation for males indicates that neither the level of education nor the education-occupation match was important in 1993. The statistically significant negative earnings effect to years of under education for females is shown below to be the main reason why the return to years of actual education for females exceeds that for males.

\section{$\underline{2004}$}

The results from the estimation of the ORU model for 2004 are reported in Table 6. These show that the wage reforms that started to take effect in the 1990s have been associated with the emergence of a highly significant wage premium to years of correctly matched education. While this wage premium characterizes both the male and female labor markets, it is around three percentage points higher for females than it is for males. 
Table 6

Estimates of ORU Model of Earnings Determination in Urban Areas, 2004

\begin{tabular}{|c|c|c|c|c|c|c|}
\hline \multirow[b]{2}{*}{ Variables } & \multicolumn{3}{|c|}{ Males } & \multicolumn{3}{|c|}{ Females } \\
\hline & (i) & (ii) & (iii) & (iv) & (v) & (vi) \\
\hline Constant & $\begin{array}{c}5.067 * * * \\
(11.85)\end{array}$ & $\begin{array}{c}4.879 * * * \\
(11.69)\end{array}$ & $\begin{array}{c}5.071 * * * \\
(10.93)\end{array}$ & $\begin{array}{c}4.475^{* * * *} \\
(9.21)\end{array}$ & $\begin{array}{c}4.231 * * * \\
(8.59)\end{array}$ & $\begin{array}{c}4.279 * * * \\
(7.82)\end{array}$ \\
\hline $\begin{array}{r}\text { Reference } \\
\text { education }\end{array}$ & $\begin{array}{c}0.096 * * * \\
(7.25)\end{array}$ & $\begin{array}{c}0.104 * * * \\
(7.82)\end{array}$ & $\begin{array}{c}0.075 * * * \\
(2.78)\end{array}$ & $\begin{array}{c}0.128 * * * \\
(8.44)\end{array}$ & $\begin{array}{l}0.130 * * * \\
(8.58)\end{array}$ & $\begin{array}{c}0.126 * * * \\
\quad(3.41)\end{array}$ \\
\hline $\begin{array}{l}\text { Over } \\
\text { education }\end{array}$ & $\begin{array}{c}0.036 * * \\
(2.40)\end{array}$ & $\begin{array}{c}0.036 * * \\
(2.39)\end{array}$ & $\begin{array}{c}0.030 * * \\
(2.00)\end{array}$ & $\begin{array}{c}0.097 * * * \\
(5.40)\end{array}$ & $\begin{array}{c}0.096 * * * \\
(5.51)\end{array}$ & $\begin{array}{c}0.092 * * * \\
(5.15)\end{array}$ \\
\hline $\begin{array}{l}\text { Under } \\
\text { education }\end{array}$ & $\begin{array}{l}-0.023 \\
(1.37)\end{array}$ & $\begin{array}{l}-0.026 \\
(1.52)\end{array}$ & $\begin{array}{l}-0.025 \\
(1.51)\end{array}$ & $\begin{array}{l}-0.030 \\
(1.15)\end{array}$ & $\begin{array}{l}-0.031 \\
(1.19)\end{array}$ & $\begin{array}{l}-0.031 \\
(1.16)\end{array}$ \\
\hline Log hours & $\begin{array}{l}0.081 \\
(0.81)\end{array}$ & $\begin{array}{l}0.084 \\
(0.83)\end{array}$ & $\begin{array}{l}0.086 \\
(0.85)\end{array}$ & $\begin{array}{l}0.040 \\
(0.38)\end{array}$ & $\begin{array}{l}0.030 \\
(0.29)\end{array}$ & $\begin{array}{l}0.034 \\
(0.33)\end{array}$ \\
\hline $\begin{array}{l}\text { Experience } \\
\text { (Exp) }\end{array}$ & $\begin{array}{l}0.005 \\
(0.45)\end{array}$ & $\begin{array}{l}0.007 \\
(0.66)\end{array}$ & $\begin{array}{l}0.006 \\
(0.56)\end{array}$ & $\begin{array}{c}0.022 * * \\
(2.34)\end{array}$ & $\begin{array}{c}0.028 * * * \\
(2.96)\end{array}$ & $\begin{array}{c}0.028 * * * \\
(2.91)\end{array}$ \\
\hline $\operatorname{Exp}^{2} / 100$ & $\begin{array}{l}-0.007 \\
(0.39)\end{array}$ & $\begin{array}{l}-0.011 \\
(0.59)\end{array}$ & $\begin{array}{r}-0.010 \\
(0.52)\end{array}$ & $\begin{array}{c}-0.043^{* *} \\
(1.98)\end{array}$ & $\begin{array}{c}-0.055^{* *} \\
(2.51)\end{array}$ & $\begin{array}{c}-0.055^{* *} \\
(2.50)\end{array}$ \\
\hline Married & $\begin{array}{c}0.236 * * * \\
(2.80)\end{array}$ & $\begin{array}{c}0.226 * * * \\
(2.76)\end{array}$ & $\begin{array}{c}0.221 * * * \\
(2.71)\end{array}$ & $\begin{array}{l}0.114 \\
(1.56)\end{array}$ & $\begin{array}{l}0.080 \\
(1.09)\end{array}$ & $\begin{array}{l}0.082 \\
(1.11)\end{array}$ \\
\hline $\begin{array}{l}\text { Rural } \\
\text { Registration }\end{array}$ & $\begin{array}{c}-0.118^{*} \\
(1.79)\end{array}$ & $\begin{array}{l}-0.074 \\
(1.08)\end{array}$ & $\begin{array}{l}-0.071 \\
(1.03)\end{array}$ & $\begin{array}{l}0.008 \\
(0.08)\end{array}$ & $\begin{array}{l}0.055 \\
(0.51)\end{array}$ & $\begin{array}{l}0.052 \\
(0.49)\end{array}$ \\
\hline State & $\begin{array}{c}0.109 * \\
(1.92)\end{array}$ & $\begin{array}{c}0.141 * * \\
(2.47)\end{array}$ & $\begin{array}{c}0.160 * * * \\
(2.72)\end{array}$ & $\begin{array}{c}0.147 * \\
(1.85)\end{array}$ & $\begin{array}{c}0.184 * * \\
(2.35)\end{array}$ & $\begin{array}{c}0.173 * * \\
(2.13)\end{array}$ \\
\hline Private & $\begin{array}{c}0.219 * * * \\
(3.14)\end{array}$ & $\begin{array}{c}0.216^{* * *} \\
\quad(3.08)\end{array}$ & $\begin{array}{c}0.236 * * * \\
(3.36)\end{array}$ & $\begin{array}{c}0.292 * * * \\
\quad(3.23)\end{array}$ & $\begin{array}{c}0.302 * * * \\
(3.49)\end{array}$ & $\begin{array}{c}0.291 * * * \\
\quad(3.34)\end{array}$ \\
\hline Central & & $\begin{array}{l}0.002 \\
(0.03)\end{array}$ & $\begin{array}{l}0.002 \\
(0.03)\end{array}$ & & $\begin{array}{c}0.207 * * * \\
(3.08)\end{array}$ & $\begin{array}{c}0.194 * * * \\
(2.93)\end{array}$ \\
\hline East & & $\begin{array}{c}0.146^{* *} \\
(2.34)\end{array}$ & $\begin{array}{c}0.149 * * \\
(2.40)\end{array}$ & & $\begin{array}{c}0.296 * * * \\
(4.53)\end{array}$ & $\begin{array}{c}0.295 * * * \\
(4.61)\end{array}$ \\
\hline Clerk & & & $\begin{array}{l}0.093 \\
(0.74)\end{array}$ & & & $\begin{array}{l}0.008 \\
(0.05)\end{array}$ \\
\hline Senior & & & $\begin{array}{l}0.175 \\
(1.18)\end{array}$ & & & $\begin{array}{l}0.122 \\
(0.70)\end{array}$ \\
\hline Junior & & & $\begin{array}{l}0.106 \\
(1.18)\end{array}$ & & & $\begin{array}{l}0.006 \\
(0.05)\end{array}$ \\
\hline Leader & & & $\begin{array}{l}0.188 \\
(1.59)\end{array}$ & & & $\begin{array}{l}-0.081 \\
(0.56)\end{array}$ \\
\hline Other & & & $\begin{array}{c}0.180 * \\
(1.80)\end{array}$ & & & $\begin{array}{l}0.089 \\
(0.70)\end{array}$ \\
\hline Adj. $R^{2}$ & 0.141 & 0.153 & 0.153 & 0.210 & 0.237 & 0.235 \\
\hline Sample size & 512 & 512 & 512 & 404 & 404 & 404 \\
\hline
\end{tabular}

Notes: Numbers in parentheses are absolute values of heteroskedasticity-consistent ' $t$ ' statistics; * denotes that the variable is significant at the $10 \%$ level; ** denotes that the variable is significant at the $5 \%$ level; *** denotes that the variable is significant at the $1 \%$ level. See the Appendix for definitions of variables.

Source: China Health and Nutrition Survey (CHNS), 2004. 
The gender differential in favor of females in the return to correctly matched education is similar to that reported by Chiswick and Miller (2010a) in their analysis of earnings determination in the Canadian labor market, and by Ren and Miller (2011) in their study of earnings outcomes in the rural labor market in China. The higher wage premium to years of correctly matched education by itself would lead to higher returns to actual years of education for both males and females in 2004 compared to 1993, and to females having a higher return to actual years of education than males in 2004. It is also to be noted that the return to years of correctly matched education is four-to-five percentage points greater than the return to years of actual education in the conventional education and experience specification of the earnings equation. This suggests that worker mobility to occupations where their formal education is usual is an important feature of the 2004 urban Chinese labor market. Whether this matching process is important among both low-skilled and high-skilled groups can be ascertained through examination of the estimated effects of the under education and over education variables.

Years of over education are also associated with significantly higher earnings, though the increase in earnings is far less for males (3-4 percentage points) than for females (around 9 percentage points). This earnings effect of years of over education would tend to lower the return to years of actual education, but more so for males than for females. The gap between the return to correctly matched education and to years of surplus education (i.e., the earnings penalty to mismatched higher education) among the better educated workers where over education tends to be a characteristic also indicates that education-occupation matching is an important feature of the higher-skilled segment of the labor market, for both males and females. 
Finally, years of under education are not associated with statistically significant differences in earnings in 2004. The absence of an earnings effect for years of under education would tend to lower the return to actual years of education, ceteris paribus. The similarity of the point estimates for the under education variable for males and females indicates that any impact on the return to years of actual education will be reasonably gender neutral. The statistical insignificance of the earnings effects associated with years of under education, in the presence of a sizeable and significant earnings effect to years of reference education, is usually argued to indicate that these undereducated workers possess other skills or attributes that substitute for formal schooling. These other attributes could include the higher levels of motivation discussed by Chiswick and Miller (2008) in relation to foreign-born workers in the US, and to business connections that might retain value in an economy in transition.

Hence, these results draw attention to a greater role for education-occupation matching in the urban labor market in 2004 than in 1993, though the divergent results for the over education and under education variables suggest that this allocative role for education was more important among the more skilled occupations.

$\underline{2006}$

The results from estimation of the ORU model using the data for 2006 are presented in Table 7. According to the results for the column (ii) specification, the return to the reference level of education for females, at 13.0 percent, exceeds that for males, of 10.5 percent. This gender differential in favor of females in the return to correctly matched education is similar to that reported for 2004, and should, ceteris paribus, translate into a lower return to actual years of education for males than for females in the Mincer model. The excess of the return to the reference level of education over the return to actual years of education by itself suggests that, as was 
the situation in 2004, worker mobility to occupations where their education levels are more common is an important aspect of earnings determination in 2006.

Table 7

Estimates of ORU Model of Earnings Determination in Urban Areas, 2006

\begin{tabular}{|c|c|c|c|c|c|c|}
\hline \multirow{2}{*}{ Variables } & \multicolumn{3}{|c|}{ Males } & \multicolumn{3}{|c|}{ Females } \\
\hline & (i) & (ii) & (iii) & (iv) & (v) & (vi) \\
\hline Constant & $\begin{array}{c}5.356^{* * * *} \\
(15.55)\end{array}$ & $\begin{array}{c}5.229 * * * \\
(15.57)\end{array}$ & $\begin{array}{c}5.643 * * * \\
(13.35)\end{array}$ & $\begin{array}{c}4.640 * * * \\
(8.67)\end{array}$ & $\begin{array}{c}4.385 * * * \\
(8.17)\end{array}$ & $\begin{array}{c}4.326 * * * \\
(7.44)\end{array}$ \\
\hline $\begin{array}{l}\text { Reference } \\
\text { education }\end{array}$ & $\begin{array}{c}0.106^{* * *} \\
(7.36)\end{array}$ & $\begin{array}{c}0.105^{* * *} \\
(7.48)\end{array}$ & $\begin{array}{l}0.053 \\
(1.53)\end{array}$ & $\begin{array}{c}0.126^{* * *} \\
(8.54)\end{array}$ & $\begin{array}{c}0.130 * * * \\
(8.52)\end{array}$ & $\begin{array}{c}0.136 * * * \\
(5.04)\end{array}$ \\
\hline $\begin{array}{l}\text { Over } \\
\text { education }\end{array}$ & $\begin{array}{c}0.080 * * * \\
(4.21)\end{array}$ & $\begin{array}{c}0.075 * * * \\
(3.99)\end{array}$ & $\begin{array}{c}0.071 * * * \\
(3.87)\end{array}$ & $\begin{array}{c}0.073 * * * \\
(3.76)\end{array}$ & $\begin{array}{c}0.076 * * * \\
(4.06)\end{array}$ & $\begin{array}{c}0.070 * * * \\
(3.83)\end{array}$ \\
\hline $\begin{array}{l}\text { Under } \\
\text { education }\end{array}$ & $\begin{array}{c}-0.037 * * \\
(2.06)\end{array}$ & $\begin{array}{c}-0.042 * * \\
(2.33)\end{array}$ & $\begin{array}{c}-0.039 * * \\
(2.23)\end{array}$ & $\begin{array}{l}-0.010 \\
(0.48)\end{array}$ & $\begin{array}{l}-0.009 \\
(0.43)\end{array}$ & $\begin{array}{r}-0.006 \\
(0.27)\end{array}$ \\
\hline Log hours & $\begin{array}{l}-0.037 \\
(0.49)\end{array}$ & $\begin{array}{l}-0.051 \\
(0.68)\end{array}$ & $\begin{array}{l}-0.040 \\
(0.55)\end{array}$ & $\begin{array}{l}0.073 \\
(0.58)\end{array}$ & $\begin{array}{l}0.064 \\
(0.52)\end{array}$ & $\begin{array}{l}0.071 \\
(0.58)\end{array}$ \\
\hline $\begin{array}{l}\text { Experience } \\
\text { (Exp) }\end{array}$ & $\begin{array}{c}0.024 * * \\
(2.13)\end{array}$ & $\begin{array}{c}0.023 * * \\
(2.03)\end{array}$ & $\begin{array}{l}0.021 * \\
(1.82)\end{array}$ & $\begin{array}{l}0.015 \\
(1.59)\end{array}$ & $\begin{array}{c}0.022 * * \\
(2.10)\end{array}$ & $\begin{array}{c}0.022 * * \\
(1.99)\end{array}$ \\
\hline $\operatorname{Exp}^{2} / 100$ & $\begin{array}{c}-0.040 * \\
(1.79)\end{array}$ & $\begin{array}{l}-0.035 \\
(1.61)\end{array}$ & $\begin{array}{l}-0.032 \\
(1.52)\end{array}$ & $\begin{array}{l}-0.023 \\
(1.22)\end{array}$ & $\begin{array}{c}-0.034 * \\
(1.74)\end{array}$ & $\begin{array}{c}-0.038 * \\
(1.92)\end{array}$ \\
\hline Married & $\begin{array}{l}0.052 \\
(0.60)\end{array}$ & $\begin{array}{l}0.031 \\
(0.35)\end{array}$ & $\begin{array}{l}0.010 \\
(0.11)\end{array}$ & $\begin{array}{l}-0.131 \\
(1.09)\end{array}$ & $\begin{array}{l}-0.176 \\
(1.42)\end{array}$ & $\begin{array}{l}-0.180 \\
(1.42)\end{array}$ \\
\hline $\begin{array}{l}\text { Rural } \\
\text { Registration }\end{array}$ & $\begin{array}{l}-0.043 \\
(0.54)\end{array}$ & $\begin{array}{l}0.006 \\
(0.08)\end{array}$ & $\begin{array}{l}0.009 \\
(0.10)\end{array}$ & $\begin{array}{l}0.062 \\
(0.79)\end{array}$ & $\begin{array}{l}0.101 \\
(1.18)\end{array}$ & $\begin{array}{l}0.102 \\
(1.21)\end{array}$ \\
\hline State & $\begin{array}{c}0.223^{* * * *} \\
(3.13)\end{array}$ & $\begin{array}{c}0.250 * * * \\
(3.49)\end{array}$ & $\begin{array}{c}0.264 * * * \\
(3.56)\end{array}$ & $\begin{array}{c}0.373 * * * \\
(5.75)\end{array}$ & $\begin{array}{c}0.384 * * * \\
(5.59)\end{array}$ & $\begin{array}{c}0.375 * * * \\
(4.99)\end{array}$ \\
\hline Private & $\begin{array}{c}0.333 * * * \\
(4.54)\end{array}$ & $\begin{array}{c}0.335^{* * * *} \\
(4.68)\end{array}$ & $\begin{array}{c}0.348 * * * \\
(4.66)\end{array}$ & $\begin{array}{c}0.281 * * * \\
(4.08)\end{array}$ & $\begin{array}{c}0.292 * * * \\
\quad(4.17)\end{array}$ & $\begin{array}{c}0.293 * * * \\
(3.97)\end{array}$ \\
\hline Central & & $\begin{array}{c}0.210 * * * \\
(2.78)\end{array}$ & $\begin{array}{c}0.200 * * * \\
(2.75)\end{array}$ & & $\begin{array}{c}0.207 * * * \\
(3.24)\end{array}$ & $\begin{array}{c}0.209 * * * \\
(3.25)\end{array}$ \\
\hline East & & $\begin{array}{c}0.232 * * * \\
(2.90)\end{array}$ & $\begin{array}{c}0.223 * * * \\
(2.86)\end{array}$ & & $\begin{array}{c}0.239 * * * \\
(2.77)\end{array}$ & $\begin{array}{c}0.244 * * * \\
(2.91)\end{array}$ \\
\hline Clerk & & & $\begin{array}{l}0.072 \\
(0.46)\end{array}$ & & & $\begin{array}{c}-0.430 \\
(0.32)\end{array}$ \\
\hline Senior & & & $\begin{array}{r}0.334^{*} \\
(1.93)\end{array}$ & & & $\begin{array}{l}0.061 \\
(0.45)\end{array}$ \\
\hline Junior & & & $\begin{array}{l}0.118 \\
(1.54)\end{array}$ & & & $\begin{array}{r}-0.035 \\
(0.36)\end{array}$ \\
\hline Leader & & & $\begin{array}{c}0.381 * * * \\
(2.65)\end{array}$ & & & $\begin{array}{c}-0.012 \\
(0.11)\end{array}$ \\
\hline Other & & & $\begin{array}{l}0.068 \\
(0.51)\end{array}$ & & & $\begin{array}{l}0.214 \\
(1.11)\end{array}$ \\
\hline Adj. $R^{2}$ & 0.168 & 0.179 & 0.198 & 0.271 & 0.284 & 0.282 \\
\hline Sample size & 536 & 536 & 536 & 404 & 404 & 404 \\
\hline
\end{tabular}

Notes: Numbers in parentheses are absolute values of heteroskedasticity-consistent ' $t$ ' statistics; * denotes that the variable is significant at the $10 \%$ level; ** denotes that the variable is significant at the $5 \%$ level; $* * *$ denotes that the variable is significant at the $1 \%$ level. See the Appendix for definitions of variables.

Source: China Health and Nutrition Survey (CHNS), 2006. 
In comparison to the situation with respect to the return to correctly matched years of education, which consistently favor females, there have been two changes between 2004 and 2006 to the earnings effects associated with years of over education and with years of under education that will lead to an increase in the return to years of actual education for males relative to that for females. Thus, the return to years of over education for males is 7.5 percent, and this is 4 percentage points higher than that recorded in 2004. The 7.5 percent return to years of over education for males is on par with the return to years of over education for females. Years of surplus education were also associated with similar increases in earnings for males and females in Ren and Miller's (2011) study of the labor market in rural China.

Years of under education are associated with an earnings penalty of -4.2 percent in the male labor market, and a statistically insignificant -0.9 percent impact on earnings in the female labor market. The statistically insignificant earnings effect for under education for females mirrors the evidence for 2004. However, the significant negative earnings effect to years of under education for males is a new phenomenon in the Chinese urban labor market. It is a typical feature of studies of the labor markets of Western countries that use the ORU model. It could reflect the squeezing out of the non-productivity related aspects of earnings determination in the low-skilled male labor market discussed above.

The insignificant wage effect to under education for females parallels the findings in Chiswick and Miller (2008) in relation to the earnings of under educated immigrants in the US economy. They report that such immigrants incur a much smaller earnings penalty than their native-born counterparts, and link this to selfselection in immigration which is more intense among the less-well educated, and which results in unskilled foreign-born workers possessing relatively more of other, 
unmeasured, skills (e.g., motivation, ability, commitment) that are favorably rewarded in the labor market. Carrying this suggestion across to the Chinese urban labor market, it would be suggested that less-well educated female urban workers are more positively self-selected for labor force participation than their male counterparts.

Thus, the distinguishing feature of the urban labor market in China in 2006, from the perspective of gender differences, appears to be in relation to the earnings effects of under education. In this regard, the evidence suggests that educationoccupation matching is not overly important in the lower-skilled segment of the labor market for females, but it is starting to become important for males. These issues are addressed further below.

\section{(iii) Decomposition analysis}

Table 8 lists the results from applying the decomposition of Chiswick and Miller (2008) to the gender differential in the return to education for males and females in urban areas in 1993. From this table, it is really apparent that the adjustments for the earnings effects of reference education and over education are associated with inconsequential changes in the return to education. This follows from the broad similarity of the estimates associated with these variables for males and females in Table 5.

The adjustment for the earnings effects of under education is, however, associated with a sharp reduction in the return to education for females: from 2.15 percent in the absence of such an adjustment, to 0.45 percent with the adjustment. The further adjustments in Table 8, for the extent of correctly matched (i.e., reference) education, over education and under education at each level of actual education, and for the distribution across actual education levels, have little effect on the return to education. In other words, the single factor contributing to the gender differential in 
the return to education in urban China in 1993 was the fact that there was a minor earnings reduction associated with years of under education among females but not among males (see Table 5).

Table 8

Implied Returns to Education, Adjusting for Effects of ORU Variables, Comparisons of Males and Females in Urban Areas, 1993

$\%$ Payoff

Males

0.77

Females

-no adjustment

(i) Assuming the same earnings effects to reference education as for males

(ii) Assuming the same earnings effects to reference education and over education as for males

(iii) Assuming the same earnings effects to reference education, over education and under education as for males

(iv) as for (iii) but also assuming the same levels of reference education, over education and under education at each level of schooling as for males

(v) as for (iv) but also assuming the same distribution across education categories for females as for males

Source: Authors calculations based on Table 5.

Table 9

Implied Returns to Education, Adjusting for Effects of ORU Variables, Comparisons of Males and Females in Urban Areas, 2004

\begin{tabular}{lc}
\hline & \% Payoff \\
\hline Males & 4.95 \\
$\begin{array}{l}\text { Females } \\
\text {-no adjustment }\end{array}$ & 8.59 \\
$\begin{array}{l}\text { (i) Assuming the same earnings effects to reference education as for males } \\
\text { (ii) Assuming the same earnings effects to reference education and over }\end{array}$ & 7.75 \\
education as for males & 5.62 \\
$\begin{array}{l}\text { (iii) Assuming the same earnings effects to reference education, over } \\
\text { education and under education as for males }\end{array}$ & 5.47 \\
$\begin{array}{l}\text { (iv) as for (iii) but also assuming the same levels of reference education, over } \\
\text { education and under education at each level of schooling as for males } \\
\text { (v) as for (iv) but also assuming the same distribution across education } \\
\text { categories for females as for males }\end{array}$ & 4.83 \\
\hline
\end{tabular}

Source: Authors calculations based on Table 6. 
Table 10

Implied Returns to Education, Adjusting for Effects of ORU Variables, Comparisons of Males and Females in Urban Areas, 2006

\begin{tabular}{lc}
\hline & \% Payoff \\
\hline Males & 7.43 \\
$\begin{array}{l}\text { Females } \\
\text {-no adjustment }\end{array}$ & 7.33 \\
$\begin{array}{l}\text { (i) Assuming the same earnings effects to reference education as for males } \\
\text { (ii) Assuming the same earnings effects to reference education and over }\end{array}$ & 6.53 \\
$\begin{array}{l}\text { education as for males } \\
\text { (iii) Assuming the same earnings effects to reference education, over }\end{array}$ & 6.49 \\
education and under education as for males & 7.50 \\
$\begin{array}{l}\text { (iv) as for (iii) but also assuming the same levels of reference education, over } \\
\text { education and under education at each level of schooling as for males } \\
\text { (v) as for (iv) but also assuming the same distribution across education } \\
\text { categories for females as for males }\end{array}$ & 7.24 \\
\hline
\end{tabular}

Source: Authors calculations based on Table 7.

Table 11

Implied Returns to Education, Detailed Adjustment for Effects of ORU Variables, Comparisons of Males and Females in Rural Areas

\begin{tabular}{lc}
\hline & \% Payoff \\
\hline Males & 3.39 \\
$\begin{array}{l}\text { Females } \\
\text {-no adjustment }\end{array}$ & 7.68 \\
$\begin{array}{l}\text { (i) Assuming the same earnings effects to reference education as for males } \\
\text { (ii) Assuming the same earnings effects to reference education and over }\end{array}$ & 6.87 \\
$\begin{array}{l}\text { education as for males } \\
\text { (iii) Assuming the same earnings effects to reference education, over }\end{array}$ & 6.86 \\
$\begin{array}{l}\text { education and under education as for males } \\
\text { (iv) as for (iii) but also assuming the same levels of reference education, over }\end{array}$ & 3.42 \\
$\begin{array}{l}\text { education and under education at each level of schooling as for males } \\
\text { (v) as for (iv) but also assuming the same distribution across education }\end{array}$ & 3.35 \\
categories for females as for males & \\
\hline
\end{tabular}

Source: Ren and Miller (2011).

Table 9 attempts to account for the larger gender difference in the returns to education in 2004. These decomposition results reveal that slightly less than one 
percentage point of this difference is due to the earnings effects to years of reference, (correctly matched) education (where females have an advantage over males of around three percentage points). However, over two percentage points of the gender gap in the return to education appears to be linked to differences in the returns to years of surplus education (the return to years of over education is about six percentage points higher for females than for males in Table 6). There is also a one percentage point effect that is traced, through the decomposition analysis, to the different distributions of male and female workers across the reference education, over education and under education categories at each level of education. Hence, these decomposition results suggest that the gender differential in the return to education is due to both a higher earnings premium to correct occupation-education matching for females, and higher earnings increments to skills that are surplus to the usual standards of the occupations in which females work. The latter result suggests that correct matching is of less importance in the high-skilled segment of the female labor market than it is for males.

Table 10 repeats the decomposition, but this time using the regressions results for 2006. This decomposition also shows that the higher return to reference years of education for females than for males translates into about a one percentage point higher return to years of actual education for females. The decomposition also shows that the earnings effects associated with years of over education do not impact the return to actual years of education: This follows from the similarity of these earnings effects in the Table 7 regression estimates for 2004. However, the decomposition shows that the differences between male and female workers in the returns to years of under education are associated with about a one percentage point lower return to actual years of schooling for females compared to males. This effect offsets that 
associated with years of reference education, to generate the approximate equality of the returns to actual years of education for male and female workers in 2006.

Table 11 presents findings of the decomposition analysis undertaken by Ren and Miller (2011) for rural China using the 2006 CHNS. It is apparent that the major difference between the results for rural areas (which conform to the conventional wisdom) and those for urban areas (which do not conform to the conventional wisdom) rests with the earnings effects of under education. Under education is associated with insignificant earnings effects for males in the rural labor market, and with a sizeable earnings penalty for males in the urban labor market. Under education is associated with insignificant earnings effects for females in the urban labor market, but with a sizeable and significant earnings penalty for females in the rural labor market. Chiswick and Miller (2008) link under education to aspects of the way workers for each group self select into the paid labor force. These results suggest that low-skilled male rural workers are more intensely selected for labor market success than their female counterparts, and that low-skilled female urban workers are more intensely selected for labor market success than their male counterparts.

\section{CONCLUSION}

The conventional wisdom on the return to education in urban China is that this has grown rapidly since the mid 1990s, and that females have a higher return than males. Chen and Hamori (2009), however, have recently reported that the return to education for males is 8.06 percent, a little higher than that for females, 7.67 percent. In the current paper the over education, required education, under education (ORU) specification of the earnings equation (Hartog, 2000) is used to examine the reasons for these patterns in the return to education in urban China, and for the recent finding by Chen and Hamori (2009). 
It is shown that neither correctly matched years of education nor mis-matched years of education were of any major consequence to the earnings determination process in urban China in the early period of the labor market reforms. However, by 2004 there were distinct differences in earnings according to the reference level of education and years of over education. Moreover, there were also considerable gender differences in the estimated impacts of these education variables. Thus, the return to years of reference education for females in 2004 was 12.8 percent, while that for males was 9.6 percent. This gender differential in favor of females in the return to correctly matched education is similar to that reported by Ren and Miller (2011) in their study of earnings outcomes in the rural labor market in China. The gender differential in the payoff to years of over or surplus education also favored females, with the payoffs being 3.6 percent for males and 9.7 percent for females. The earnings effect of years of under education, however, was not statistically significant for either males or females in 2004.

By 2006 there appear to have been two further changes to the earnings determination process in urban China. First, the return to years of over education for males increased, to reach parity with that for females. Years of surplus education were also associated with similar increases in earnings for males and females in Ren and Miller's (2011) study of the 2006 labor market in rural China. Second, an earnings penalty, of -4.2 percent, for years of under education emerged in the male labor market, but not in the female labor market. This earnings effect for males is similar to that observed in the labor markets of Western countries. It was argued above that this change could reflect the squeezing out of the non-productivity related aspects of earnings determination in the low-skilled male labor market. 
Each of these gender differences in the returns to the reference levels of education, years of over education and years of under education, can be linked, via the decomposition of Chiswick and Miller (2008) decomposition, to the differences in the return to education for females and males in a particular survey year. In 2004, the higher return to the reference level of education was associated with about a one percentage point higher return to actual years of education for females. The higher payoff to surplus education was similarly associated with about a two percentage points higher return to actual years of education for females. In 2006, however, while the effect due to reference levels of education remained as a one percentage point higher return to actual years of education for females, this was offset by a one percentage point lower return to actual years of education due to the gender difference in the returns to years of under education. The effect associated with years of surplus education had disappeared by 2006, as years of surplus education were rewarded comparably for males and females. Consequently, the returns to actual years of education for males was similar to that for females.

Comparison with the findings from Ren and Miller (2011) for rural China reveals that the main difference is in relation to the earnings effects of under education. There appears to be more intense selection into the labor market among males in rural areas and among females in urban areas. These self-selection mechanisms need to be considered before discounting the Chen and Hamori (2009) results. Indeed, Chen and Hamori (2009) find that once account is taken of potential sample selection bias, the gender differential in the payoff to schooling is reversed, to align with the conventional wisdom. Nevertheless, whether this minor gender difference in the return to schooling is unique to recent waves of the China Health and 
Nutrition Survey, or holds for other recently collected data, is a direction for future research. 


\section{REFERENCES}

Chen, G. and Hamori, S., (2009). "Economic Returns to Schooling in Urban China: OLS and the Instrumental Variables Approach", China Economic Review, Vol. 20(2), pp. 143-152.

Chen, L. and Ju, G., (2004). "An Empirical Analysis of Gender Differences in Mincerian Rate of Returns to Education", Peking University Education Review, Vol. 2(3), pp. 44-45.

Chiswick, B. R. and Miller, P. W., (2008). "Why is the Payoff to Schooling Smaller for Immigrants?", Labour Economics, Vol. 15(6), pp. 317-1340.

Chiswick, B. R. and Miller, P. W., (2010a). "An Explanation for the Lower Payoff to Schooling for Immigrants in the Canadian Labour Market", in Ted McDonald, Elizabeth Ruddick, Arthur Sweetman, and Christopher Worswick (eds.), Canadian Immigration: Economic Evidence for a Dynamic Policy Environment, Montreal: McGill-Queen's University Press, pp. 41-76.

Chiswick, B. R. and Miller, P. W., (2010b). "Does the Choice of Reference Levels of Education Matter in the ORU Earnings Equation?", Economics of Education Review Economics of Education Review, Vol. 29(6), pp. 1076-1085.

Fleisher, B.M. and Wang, X., (2005). "Returns to Schooling in China under Planning and Reform", Journal of Comparative Economics, Vol. 33(2), pp. 265-277.

Gustafsson, B. and Li, S., (2000). "Economic Transformation and the Gender Earnings Gap in Urban China”, Journal of Population Economics, Vol. 13(2), pp. 305-329.

Hartog, J., (2000). "Over-education and Earnings: Where are We, Where Should We Go?", Economics of Education Review, Vol. 19(2), pp. 131-147.

Knight, J. and Song, L., (2003). "Increasing Urban Wage Inequality in China: Extent, element and evaluation”, Economics of Transition, Vol. 11(4), pp. 597-619.

Lai, D., (1998). "Education, Labor Market and Income Distributions", Economic Research, Vol. 5, pp. $42-49$ (in Chinese).

Li, H., (2003). "Economic Transition and Returns to Education in China", Economics of Education Review, Vol. 22(3), pp. 317-328.

Li, S. and Li, W., (1994). "The Estimation of Individual Returns to Education in China's Education Investment", in R. Zhao, S. Li and C. Riskin (eds), Studies on Income Distribution of Chinese Residents, China Society Science Press, pp. 442-456.

Li, S. and Ding, S., (2003). "The Long Term Change in Private Returns to Education in Urban China", China Society Science, Vol. 6, pp. 58-72. 
Liu, Z., (1998). "Earnings, Education, and Economic Returns in Urban China", Economic Development and Cultural Change, Vol. 46(4), pp. 697-725.

Maurer-Fazio, M., (1999). "Earnings and Education in China's Transition to a Market Economy: Survey Evidence from 1989 and 1992", China Economic Review, Vol. 10, pp. 17-40.

Meng, X., (1998). "Male-female Wage Determination and Gender Wage Discrimination in China's Rural Industrial Sector", Labour Economics, Vol. 5(1), pp. 67-89.

Meng, X. and Kidd, M.P., (1997). "Labor Market Reform and the Changing Structure of Wage Determination in China's State Sector during the 1980s", Journal of Comparative Economics, Vol. 25, pp. 403-421.

Miller, P.W. and Ren, W., (2011). "Educational Mismatch in the Chinese Labor Market", in Human Capital and Resources: Developments, Management and Strategies, edited by M.F. Rizzo and A. Gallo, Nova Science Publishers, Inc.

Ren, W. and Miller, P.W., (2011). "Gender Differentials in the Payoff to Schooling in Rural China", Journal of Development Studies, forthcoming.

Tan, L. and Jiang, Y. (2008). "Gender Equality and Women's Development under the Background of the Construction of a Harmonious Society and the Improvement of People's Life", in Tan L. (ed.), Report on Gender Inequality and Women's Development in China: 1995-2005 (Green Book of Women), Beijing: Social Sciences Academic Press.

Yang, D.T., (2005). "Determinants of Schooling Returns During Transition: Evidence from Chinese Cities", Journal of Comparative Economics, Vol. 33(2), pp. 244-264.

Zhang, J., Zhao Y., Park A. and Song, X., (2005). "Economic Returns to Schooling in Urban China, 1988 to 2001", Journal of Comparative Economics, Vol. 33(4), pp. 730-752. 


\section{APPENDIX \\ Table 1 \\ Definition of Variables}

\begin{tabular}{|c|c|}
\hline Variable & Definition \\
\hline \multicolumn{2}{|c|}{ Dependent Variable } \\
\hline Log Earnings & Natural logarithm of average monthly earnings. \\
\hline \multicolumn{2}{|c|}{ Independent Variables } \\
\hline $\begin{array}{l}\text { Years of } \\
\text { Education }\end{array}$ & $\begin{array}{l}\text { Actual years of schooling, which is entered into the estimating equation as a } \\
\text { continuous variable. }\end{array}$ \\
\hline $\begin{array}{l}\text { Required } \\
\text { Education }\end{array}$ & $\begin{array}{l}\text { Years of required schooling based on the mean value of education for every } \\
\text { occupation. This is a continuous variable. The values vary across survey years. } \\
\text { Data for } 2006 \text { are presented in Table } 2 \text {. }\end{array}$ \\
\hline $\begin{array}{l}\text { Over } \\
\text { education }\end{array}$ & $\begin{array}{l}\text { Years of over education, which is the number of years of schooling in excess of } \\
\text { the required level of education. }\end{array}$ \\
\hline $\begin{array}{l}\text { Under } \\
\text { education }\end{array}$ & $\begin{array}{l}\text { Years of under education, which is the number of years of schooling less than } \\
\text { the required level education. }\end{array}$ \\
\hline Log hours & Natural logarithm of hours worked in the past week. \\
\hline Experience & Years of potential labor market experience, measured as: age-schooling- 6 . \\
\hline Female & Dichotomous variable: Female $=1$ if female, and Female $=0$ if male. \\
\hline Married & Dichotomous variable: Married $=1$ if married, and Married $=0$ otherwise. \\
\hline $\begin{array}{l}\text { Rural } \\
\text { Registration }\end{array}$ & $\begin{array}{l}\text { Dichotomous variable, set equal to } 1 \text { for rural registration, and set equal to } 0 \text { for } \\
\text { urban registration. }\end{array}$ \\
\hline Central $^{(1)}$ & $\begin{array}{l}\text { Dichotomous variable: Central=1 if located in the central areas, and Central=0 } \\
\text { otherwise. }\end{array}$ \\
\hline East & $\begin{array}{l}\text { Dichotomous variable: East }=1 \text { if located in the Eastern areas and East }=0 \\
\text { otherwise. }\end{array}$ \\
\hline State $^{(2)}$ & $\begin{array}{l}\text { Dichotomous variable for ownership: State }=1 \text { if the individual works in a } \\
\text { government department, state service/institute or state-owned enterprise, and } \\
\text { Stat }=0 \text { if otherwise. }\end{array}$ \\
\hline Private & $\begin{array}{l}\text { Dichotomous variable for ownership: Private }=1 \text { if the individual works in a } \\
\text { private enterprise such as family contract farming, private, individual enterprise } \\
\text { or three-capital enterprise (owned by foreigners, overseas Chinese and joint } \\
\text { ventures), and Private }=0 \text { if otherwise. }\end{array}$ \\
\hline Clerk $^{(3)}$ & $\begin{array}{l}\text { Dichotomous variable for occupation: Clerk }=1 \text { if the individual works as an } \\
\text { office staff (secretary, office helper) or an ordinary soldier, policeman, and } \\
\text { Clerk }=0 \text { if otherwise. }\end{array}$ \\
\hline Junior & $\begin{array}{l}\text { Dichotomous variable for occupation: Junior }=1 \text { if the individual works as a } \\
\text { junior professional/technical worker, skilled worker (foreman, group leader, } \\
\text { craftsman) or driver, and Junior }=0 \text { if otherwise. }\end{array}$ \\
\hline Senior & $\begin{array}{l}\text { Dichotomous variable for occupation: Senior }=1 \text { if the individual works as a } \\
\text { senior professional/technical worker (doctor, professor, lawyer, architect, } \\
\text { engineer), and Senior }=0 \text { if otherwise. }\end{array}$ \\
\hline Leader & $\begin{array}{l}\text { Dichotomous variable for occupation: Leader }=1 \text { if the individual works as an } \\
\text { administrator/executive/manager (working proprietor, government official, } \\
\text { section chief, department director, administrative cadre, village leader) or an } \\
\text { army officer, police officer, and Leader }=0 \text { if otherwise. }\end{array}$ \\
\hline Other & $\begin{array}{l}\text { Dichotomous variable for occupation: Other }=1 \text { if the worker's occupation is } \\
\text { unknown, and Other }=0 \text { if otherwise. }\end{array}$ \\
\hline
\end{tabular}


Table 2

Occupations and Mean Level of Schooling within Each Occupation for 2006

\begin{tabular}{|llc|}
\hline & Occupation & $\begin{array}{c}\text { Mean } \\
\text { Schooling }\end{array}$ \\
\hline 1 & $\begin{array}{l}\text { Senior professional/technical worker (doctor, professor, lawyer, architect, } \\
\text { engineer) }\end{array}$ & 12.934 \\
2 & $\begin{array}{l}\text { Junior professional/technical worker (midwife, nurse, teacher, editor, } \\
\text { photographer) }\end{array}$ & 12.656 \\
3 & Administrator/executive/manager (working proprietor, government official, & \\
& section chief, department or bureau director, administrative cadre, village leader) & 11.789 \\
4 & Office staff (secretary, office helper) & 12.460 \\
5 & Farmer, fisherman, hunter & 5.679 \\
6 & Skilled worker (foreman, group leader, craftsman) & 9.460 \\
7 & Non-skilled worker (ordinary laborer, logger) & 8.093 \\
8 & Army officer, police officer & 13.375 \\
9 & Ordinary soldier, policeman & 11.100 \\
10 & Driver & 9.137 \\
11 & Service worker (housekeeper, cook, waiter, doorkeeper, hairdresser, counter & 8.797 \\
& salesperson, launderer, child care worker) & 10.934 \\
12 & Athlete, actor, musician & 8.431 \\
\hline 13 & Other & \\
\hline
\end{tabular}

